\title{
Suitability of the Spanish Open Public Cartographic Resources for BIM Site Modeling
}

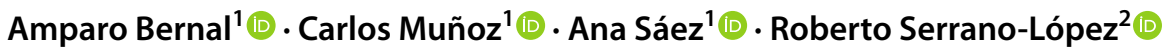

Received: 16 June 2021 / Accepted: 7 September 2021 / Published online: 2 November 2021

(c) The Author(s) 2021

\begin{abstract}
The possibility of accessing free cartographic resources on the internet instead of creating their own digital object representation is a big advantage for architecture and engineering professionals in the surveying process of a construction or restoration project. The use of these products must be carried out with the guarantee that the precision of the site representation made from them is adapted to the level of detail required by each phase of the project. This paper compares graphically and statistically the accuracy of the topographic surfaces we can get from the LIDAR point clouds and the Digital Terrain Models (DTMs) of the National Centre for Geographic Information (CNIG by its Spanish acronym) that in Spain are available on the internet free of charge. We will use as a reference surface for comparison, the topographic map of the Digital Model Elevation (DEM) from the images captured by an unmanned aerial vehicle (UAV) processed with software based on algorithms of Structure from Motion (SfM). The study case for this comparative research will be the graphical survey of an archaeological site of funerary architecture made in 1939 during the Spanish Civil War. The monument is located near the city of Burgos (Spain) in an area with difficult access and restricted airspace, which makes difficult the fieldwork. The modeling of the surface has great importance for the graphic survey of the site, because its architectural configuration is adapted to the steep slope of the hillside. The purpose of this research is to check, if the surfaces provided through the Spanish open public cartographic resources are accurate enough to replace the mapping from UAV photogrammetry. Finally, if the outcomes can be extrapolated for widespread use of these resources for the site modeling of a project, according to the requirements of the different levels of development defined in the Building Information Modeling (BIM) methodology.
\end{abstract}

Keywords Free cartographic resources · LIDAR · UAV photogrammetry · Spanish Civil War Architecture · Site modeling · BIM methodology

\section{Zusammenfassung}

Eignung der spanischen offenen öffentlichen kartografischen Ressourcen für die BIM-Modellierung. Die Möglichkeit, auf kostenlose kartografische Ressourcen im Internet zuzugreifen, anstatt eine eigene digitale Objektrepräsentation zu erstellen, ist ein großer Vorteil für Beteiligte eines Bau- oder Restaurierungsprojekts. Bei der Verwendung dieser Produkte muss gewährleistet sein, dass die Genauigkeit der damit erstellten Darstellung für den für die jeweilige Projektphase erforderlichen Detaillierungsgrad ausreichend ist. Dieser Beitrag vergleicht grafisch und statistisch die Genauigkeit der topografischen Oberflächen, die wir aus den LIDAR-Punktwolken und den Digitalen Geländemodellen (DGM) des Nationalen Zentrums für Geografische Information (CNIG) erhalten können, die in Spanien kostenlos im Internet zur Verfügung stehen. Als Referenzfläche für den Vergleich wird die topografische Karte des Digitalen Höhenmodells (DEM) verwendet, die aus den

Amparo Bernal

amberlop@ubu.es

Carlos Muñoz

carmusa@ubu.es

Ana Sáez

ash0018@alu.ubu.es

Roberto Serrano-López

robertosl@ubu.es
1 Department of Graphic Expression, Universidad de Burgos, Burgos, Spain

2 Department of Civil Engineering, Universidad de Burgos, Burgos, Spain 
von einem unbemannten Luftfahrzeug (UAV) aufgenommenen Bildern stammt und mit einer auf Algorithmen der Structure from Motion (SfM) basierenden Software verarbeitet wurde. Der Studienfall für diese vergleichende Forschung ist die grafische Vermessung einer archäologischen Stätte der Grabarchitektur aus dem Jahr 1939 während des spanischen Bürgerkriegs. Das Denkmal befindet sich in der Nähe der Stadt Burgos (Spanien) in einem Gebiet mit schwierigem Zugang und eingeschränktem Luftraum, was die Feldarbeit erschwert. Die Modellierung der Oberfläche ist für die grafische Erfassung der Stätte von großer Bedeutung, da die architektonische Gestaltung an den steilen Abhang angepasst ist. Ziel dieser Untersuchung ist es, zu prüfen, ob die mit den öffentlichen spanischen kartografischen Ressourcen erstellten Oberflächendaten genau genug sind, um die Kartierung durch UAV-Photogrammetrie zu ersetzen. Schließlich soll geprüft werden, ob die Ergebnisse für eine breite Nutzung dieser Ressourcen für die Standortmodellierung eines Projekts extrapoliert werden können, entsprechend den Anforderungen der verschiedenen Entwicklungsstufen, die in der Methodik des Building Information Modeling (BIM) definiert sind.

\section{Introduction}

Architecture and engineering are the main disciplines that have always needed cartographic products to elaborate their analyses, studies, and projects. Currently, the possibility of having various cartographic resources available on the internet has boosted the interaction of geospatial information with multiple disciplines and, in turn, has generated a growing dependence on cartography for the elaboration of any type of analysis or study (Quirós and Polo 2018).

Maps are no longer instruments of exclusive professional use. They have become a transversal tool whose use covers all areas of our social, economic, and cultural life (Moreira 2001). It could even be stated that, nowadays, if there is no cartography appropriately accurate to the scale of the study and with a certain accuracy in the representation of data and symbology, the study will lack value or consistency (Odón Rodríguez 2009).

According to the information provided by the European Data Portal, geographic data from the Spatial Data Infrastructure of Spain (IDEE in Spanish) are the second most consulted category of data in this country after the government data, which heads the list. In addition, we must take into consideration that data from the National Geographic Institute (IGN in Spanish) are the third most consulted category in this portal (European Union 2020).

The possibility of drawing the topographic site map of an architectural project directly from one of the public cartographic resources available on the internet is a great competitive advance for all users, but especially for professionals in the field. The use of these products could avoid hiring services for the elaboration of an own cartography in the initial phases of the restoration or construction project. Especially, if we consider that, many of those previous studies are often developed before contracting the professional services of the architect or engineer who will carry out the project.

Previtali and Valente state in a recent study that the use of open data is the end of a process that goes from discovery and selection of the appropriate sources to access through request and delivery, according to the protocols for publishing such data (Previtali and Valente 2019). In addition to this process, the use of open data must be supported by checking the reliability of the source and its accuracy.

In relation to this process, there is a reference paper focused on showing the different cartographic resources in Spain, their accessibility, and possibilities of use (Quirós and Polo 2018). Regarding the reliability of the data, as with any type of free information available on the web, it is necessary to check the accuracy of the topographic map that can be drawn from the free cartographic resources, because it will allow the designer to choose them in accordance with the accuracy required by the study or project (Lorenzo et al. 2012).

The aim of this study is to compare the accuracy of the topographic representations of an archaeological site obtained from the public cartographic resources of CNIG, regarding the surface created by UAV photogrammetry.

Finally, the purpose of this comparative analysis is to establish a connection between the use of each cartographic resource checked and the level of development required by the site modeling in each phase of the project assimilating every phase to the levels of development defined by the BIM methodology for the architecture project (American Institute of Architects 2013).

This research study is carried out within the framework of a research project on archaeological monuments of architectural scenery built in the province of Burgos (Spain) during the Spanish Civil War (Bernal 2018). The archaeological site chosen to carry out this study is the funeral monument to General Mola built in 1939 on a steep slope situated between the municipalities of Valle de Oca and Alcocero de Mola, 35 kms north of the city of Burgos in the Community of Castilla y León. The existence of an archaeological monument built on this slope has kept this strip of land free of vegetation in the middle of a pine tree forest planted at the beginning of the 1950s with the intention of beautifying this place (Archivo Histórico Provincial de Burgos 1954) (Fig. 1). 


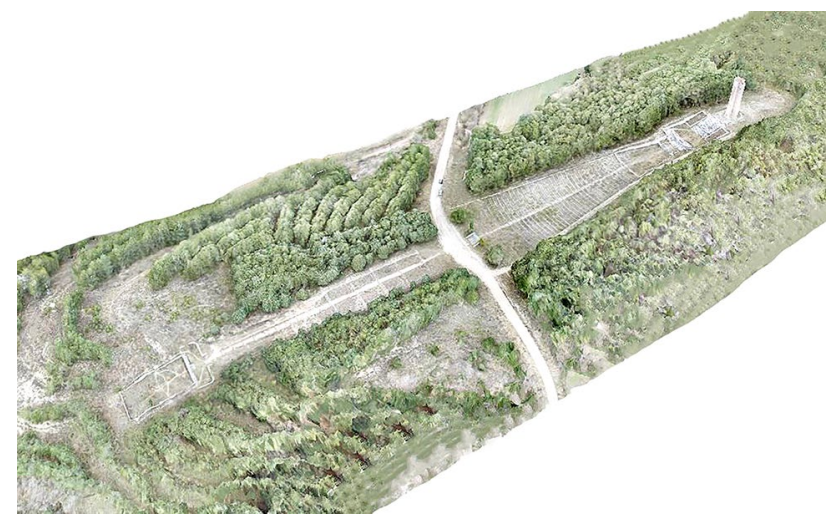

Fig. 1 Photogrammetric model of the study area

\section{Selection of Cartographic Resources}

Currently, apart from the more complex techniques such as radargrammetry and radar interferometry, the main techniques that allow obtaining altimetry data to create DTMs are photogrammetry and LIDAR (Jakovljevic et al. 2019; Salach et al. 2018; Höhle and Höhle 2009). UAV photogrammetry has recently become one of the most employed systems for mapping and 3D modeling of archaeological and architectural documentation, because it is the low-cost alternative to the aerial photogrammetry technique (Peinado Checa et al. 2014).

There are several recent studies comparing the quality of surveys performed with LIDAR technology and UAV photogrammetry (Lorenzo et al. 2012; Chiabrando et al. 2017; Bandini et al. 2020). Regarding the use of free cartographic resources, we must consider the studies that demonstrate the accuracy achieved in cartographic representation using free cartographic products like time series Landsat imagery and the Google Earth Engine (Wang et al. 2020), free DEMs (Tavares da Costa et al. 2019), or a combination of multiple data sources (Cantemir et al. 2016). This research study is focused on the cartographic products made by the Spanish National Geographic Institute (IGN in Spanish). All these data are published on the Download Centre of the CNIG website. The CNIG is a public body attached to the ING created in 1989. One of the main responsibilities of the CNIG is to guarantee the quality of the published data, as well as its reuse to create products and services that meet the demands of citizens (Instituto Geográfico Nacional 2020a).

The IGN has been improving the quality of the available resources as technological advances have made it possible to obtain increasingly precise and varied cartographic products. The first photogrammetric flights of the National Plan for Aerial Orthophotography (PNOA in Spanish) in 2004 were planned to obtain digital aerial orthophotographs with a resolution of 25 or $50 \mathrm{~cm}$. The DEMs built with these data were updated every 2 or 3 years (Odón Rodríguez 2009; Quirós and Polo 2018).

The first DTMs were made by interpolations between level curves of $10 \mathrm{~m}$ of equidistance, with a "Root Mean Squared Error" in the "z" axis of 2-3 m (RMSE 2-3 m). These DTMs considerably simplified the shape of the terrain ant they did not reflect the landform well enough. Subsequently, they began to be drawn directly by photogrammetric stereo-correlation, and as technology improved, they gradually passed from manual restitution processes to automatic ones.

Spain was a pioneer in the use of LIDAR technology launching the PNOA-LIDAR project in 2008. Compared to photogrammetric techniques, LIDAR has the potential to go through the forest cover and get information about the ground and other elements located below it. The points from the LIDAR point cloud can be classified by categories such as land surface, high trees areas, low vegetation, or buildings (Baltsavias 1999). Furthermore, as some authors have marked, LIDAR technique is less influenced by atmospherical conditions and light than aerial photogrammetry (Lorenzo et al. 2012; Chiabrando et al. 2017).

The development of the Spanish PNOA-LIDAR project between 2008 and 2015 led to the first coverage of points for the entire national territory with this technology with an average density, depending on the area, of one point for every $2 \mathrm{~m}^{2}$ and accuracy in altimetry of $20 \mathrm{~cm}$. The second coverage increases the average density of the point cloud to four points per square meter, even higher in some regions. The flights of the second coverage have already finished, but their data are not yet available for the entire Spanish territory. The very nature of this cooperative and co-financed project between the Spanish State and the Autonomous Communities has entailed a heterogeneous development throughout the country. In the autonomous community of Castilla y León, currently available data are those corresponding to the first coverage with a density of 0.5 points per square meter (Instituto Geográfico Nacional 2020b).

Currently, all the DTMs published on the CNIG website-DTM02, DTM05, DTM25, and DTM200—are created from the LIDAR point cloud, and they are available to download free of charge (Centro Nacional de Información Geográfica 2020a). The number of every DTM relates to the mesh pitch resolution of 2, 5, 25, and $200 \mathrm{~m}$ in grid size used to get their surfaces. DTM02 is not available for entire Spanish territory, so we cannot use it for this research study. DTM05 is created directly from the LIDAR point cloud by rasterizing the lowest point of the point cloud classified as ground in a $5 \times 5 \mathrm{~m}$ grid, respectively. DTM 25 and DTM200 are made from DTM05 by bilinear interpolation. All the regular three-dimensional mesh is available for free download on the website. 
Theoretically, the technical specifications of LIDAR 1st coverage guarantee RMSEz under 0.4 m (Instituto Geográfico Nacional 2020b). However, the metadata of LIDAR 1st coverage downloaded from the from the website of the CNIG Download Centre assign an RMSEz under $0.20 \mathrm{~m}$ (1 sigma) to the LIDAR 1st coverage (Centro Nacional de Información Geográfica 2020b). We can use LIDAR data to create a surface or to make other denser but more heterogeneous terrain models useful for different purposes of analysis and disciplinary studies, so the accuracy will be different according to the calculation process of the data.

In addition to the DTMs and LIDAR data mentioned above, the PNOA-LIDAR project offers other free access cartographic products on the Download Centre of the CNIG website such as Digital Surfaces Models, Building Digital Surfaces Models, Vegetation Digital Surfaces Models, Slopes Digital Surfaces Models, and LIDAR Maps (Centro Nacional de Información Geográfica 2020a).

We have only selected the free cartographic resources DTM25, DTM05, and LIDAR data for this study, but this research intends to open a line of research for new experimental studies focused on comparing and analyzing data from the open public cartographic resources in Spain and other countries with a similar geographic data advertising policy.

\section{Research Methodology}

The methodology of this research study is based on a comparative study of the accuracy of the selected free cartographic resources regarding the surface carried out by UAV photogrammetry. The basis for comparison will be the maps made from them. Maps are essential instruments in the representation of architecture and this research is focused on the survey of an architectural site. Furthermore, the final objective of the research is to find conclusions about the use of open public cartographic resources for BIM site modeling in the architectural project.

We will process the data of DTM25, DTM05, and LIDAR point cloud draw the contour line maps at one meter of equidistance. We have not chosen the DTM200, because the data of this cartographic resource do not allow drawing one meter equidistant level curves, which complicates a homogeneous comparison between the other surfaces.

We will also process the photographs taken by UAV photogrammetry with the SfM software to get the DEM and then draw the surface with contour lines. First, we will calculate the RMSEz of every surface to prove the quality of the UAV photogrammetric surface that we will use as the model for comparison. Subsequently, we will compare the vertical accuracy of the surfaces along a longitudinal profile generated on the maximum gradient of the slope. The conclusions of this analysis will be considered to select the most suitable cartographic products to represent the landform in every stage of BIM site modeling.

The "Map comparator" on the IGN website was a reference for this methodology. Its interface allows the superposition of different maps, historical aerial photographs, DTMs, LIDAR point clouds, and other layers of administrative information such as the land registry. This interface displays graphically the difference between the representations of the terrain of each cartographic resource selected and shows the metadata information. However, it does not allow us to analyze the precision of the topographic surfaces that we could draw from them (Instituto Geográfico Nacional-Centro Nacional de Información Geográfica 2020).

\subsection{The Process of Obtaining Surfaces}

Each type of cartographic product comes from a source with different kind of data files. Thus, each type of file requires a calculation process until obtaining the topographic surface that we will later use for comparison. In every case, surfaces, contour lines and profiles are generated with the MDT8 software, a specific application for topography and civil engineering installed as a complement on AutoCAD. The MDT8 software generates surfaces by triangulation of the point cloud. These triangles form a triangulated irregular network (TIN) that accurately represents the shape of the terrain.

We start calculating the surface from the DEM of UAV photogrammetry, because it will be the model used as a reference for comparison. The archaeological site where this study case is carried out is located in a restricted flight zone considered as a "dangerous airspace". Therefore, it was necessary to request flight permission from the military authorities before carrying out the fieldwork with the drone. The UAV available for this research study was a "DJI Mavic Pro" drone equipped with a 12-megapixel camera. The flight plan and the photographic shots were programmed using the "Drone Deploy" software. The software allows us to program a double flight grid with orthogonal shots and a circular flight around the archaeological site with oblique shots. This flight plan was chosen, because numerous studies in the field of aerial photogrammetry have demonstrated the importance of oblique shots to get better results in the documentation of vertical architectural elements (Rupnik et al. 2013, 2014; Wiedemann and More 2012; Chiabrando et al. 2017).

Due to the steep slope of the terrain, the study area was divided into two parts for different flights, so that the average height of the drone was $25 \mathrm{~m}$, and the maximum height was $40 \mathrm{~m}$ from the ground. The existence of a dense forest mass surrounding the site did not allow a closer flight. To be able 
Table 1 Photogrammetric flight parameters and GCP coordinates

\begin{tabular}{|c|c|}
\hline Drone (UAV) & DJI Mavic Pro \\
\hline Camera resolution & $12 \mathrm{Mpx}$ \\
\hline Work reference system & WGS 84 (EPGS:4326) \\
\hline \multirow[t]{4}{*}{ Ground control points (GCP) 4} & GCP 1: 470,217.001, 4,699,911.972, 970.042 \\
\hline & GCP 2: 470,239.094, 4,699,864.765, 970.521 \\
\hline & GCP 3: 470,367.778, 4,699,960.905, 995.217 \\
\hline & GCP 4: 470,090.016, 4,699,832.799, 950.347 \\
\hline GCP reference system & $\begin{array}{l}\text { ETRS89/UTM zone } 30 \mathrm{~N} \text {-EPSG:25,830-orthometric heights- } \\
\text { GRS80 reference ellipsoid—Geodesic vertex } n .20,113 \\
(462,006,850 ; 4,694,116,841)\end{array}$ \\
\hline Software & Drone deploy \\
\hline Type of flight & Dual grid and circular flight with oblique shots \\
\hline Longitudinal overlap & $80 \%$ \\
\hline Crosswise overlap & $80 \%$ \\
\hline Speed & $300 \mathrm{~m} / \mathrm{s}$ \\
\hline Flight altitude & $40 \mathrm{~m}$ \\
\hline
\end{tabular}

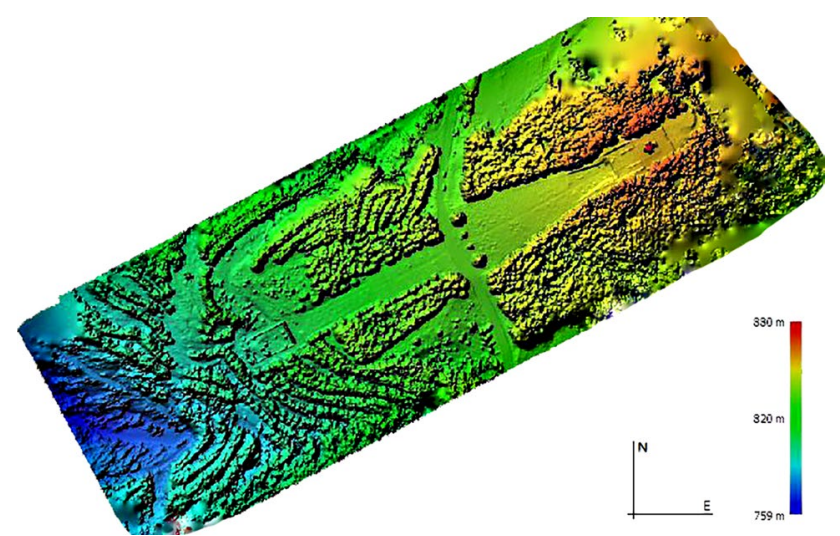

Fig. 2 Digital Elevation Model obtained with Agisoft Metashape

to subsequently georeference the model in data processing, we chose four Ground Control Points (GCP) distributed at the ends of the flight zone. We took UTM coordinates of the four GCPs, in the ETRS89 zone 30 with a Global Navigation Satellite System (GNSS) GS15 Leica receiver with RTK connection to the virtual reference station ITACYL of the Castilla y León GNSS Station Network, with an estimated accuracy of 2-3 cm (Table 1). Vertical data from GNSS with respect to the GRS80 reference ellipsoid were transformed into orthometric heights according to the correction from the closest geodesic vertex, number 20113 located in Barrios de Colina, coordinates ETRS89 (462006850; 4694116841).

The photogrammetric process was carried out applying structure-from-motion (SFM) algorithms using Agisoft Metashape software where we have process 908 photographs taken by the UAV. Following the workflow of the software, the dense point cloud was created, and the model was georeferenced by positioning the coordinates of the GCPs to subsequently obtain the DEM (Fig. 2). The first DEM was not valid to draw the terrain surface in the topographic software MDT8 because, unlike the LIDAR data, the SfM point cloud does not allow the topographic software MDT8 to automatically classify the points into different categories like: land surface, high trees areas, low vegetation, or buildings. Thus, it was necessary to manually select and delete the points of the dense point cloud corresponding to the forest surrounding the study area to avoid distortions in the creation of the topographic surface and the subsequent drawing of the contour lines.

This process of deleting points was carried out in the photogrammetric dense point cloud where the points of the trees could be unmistakably identified by turning the point cloud on itself. Once we achieved to isolate the ground point cloud, the file was exported choosing the "las" format for the point cloud data. This file could be opened with MDT8 where it will be processed to generate a topographic surface by triangulation of the point cloud. Subsequently, once the surface has been created, we can draw the contour lines and generate profiles.

The process of obtaining surfaces with contour lines from the DTMs of the CNIG is the same for all of them. DTMs files of the study area are downloaded from the website of the CNIG Download Centre as raster files with extension "asc" which contain the information encoded as text (Centro Nacional de Información Geográfica 2020a). They cannot be opened directly in MDT8, so it is necessary to process the files with the open-source software of Geographic Information Systems QGIS. The workflow through QGIS using the Python plugin "Point Sampling Tool" turns the raster file into a surface image format called "geotif" that can be processed in MDT8 in the same way we have calculated the UAV surface. 


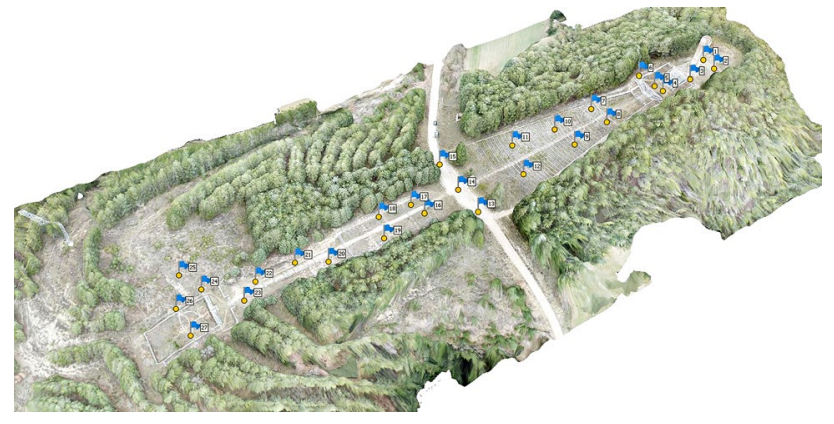

Fig. 3 Location of the 27 control points on the ground

Finally, we processed the LIDAR data to create a surface. The LIDAR point cloud of the study area from the first Coverage of PNOA-LIDAR project is also available for downloads on the website of the CNIG Download Centre. We can download a file of a grid of $2 \times 2 \mathrm{kms}$ in length in a compressed "laz" format. It must be decompress using the "LAStools" developed by Martin Isenburg (2013) to process it in other software. Once we have the LIDAR point cloud decompressed, it is necessary to filter the data to keep only the points of the ground before generating the surface. We can make this process using the algorithm "Ground filter" from the specific software "Fusion" trough QGIS or, we can filter the LIDAR point cloud trough MDT8 using the "LAS Categories" tab to select the points of the ground of the LIDAR point cloud. Later, we calculated the surface in the same way as the previous ones.

\subsection{Comparison Between Surfaces and Longitudinal Profiles}

We must prove the quality of every surface and specially the accuracy of the UAV-SfM surface that we will use as a reference. According to the research studies of Agüera-Vega et al. (2017), the RMSEz is the most common and valid statistical value to evaluate a UAV photogrammetric surface. The RMSE is applied to the " $\mathrm{z}$ " coordinate deviation of a series of control points on the ground, comparing their orthometric heights with the " $z$ " coordinates of each point on the UAV photogrammetric surface we use as model. We have also used this statistical value to evaluate the accuracy of every cartographic product.

To evaluate the RMSEz of the model and the other surfaces, UTM coordinates, in the ETRS 89 zone, 30 of 27 control points of the terrain have been measured to placed them
Table 2 Comparison of orthometric heights of the control points and RMSEz of every surface

\begin{tabular}{|c|c|c|c|c|c|c|c|}
\hline \multirow{2}{*}{$\begin{array}{l}\text { Control } \\
\text { points }\end{array}$} & \multicolumn{3}{|c|}{ coordinates GPS } & \multirow{2}{*}{$\frac{D T M 25}{Z}$} & \multirow{2}{*}{$\frac{D T M 05}{Z}$} & \multirow{2}{*}{$\frac{\text { LIDAR }}{Z}$} & \multirow{2}{*}{$\frac{\text { UAV-SfM }}{Z}$} \\
\hline & $x$ & $Y$ & $\mathbf{Z}$ & & & & \\
\hline P1 & 470362,69 & 4699959,46 & 995,980 & 993,859 & 996,229 & 996,467 & 996,205 \\
\hline $\mathrm{P} 2$ & 470366,23 & 4699952,08 & 995,940 & 991,901 & 996,094 & 996,452 & 996,243 \\
\hline P3 & 470349,52 & 4699942,65 & 996,110 & 992,493 & 996,240 & 996,535 & 996,443 \\
\hline $\mathrm{P} 4$ & 470334,58 & 4699937,45 & 991,840 & 992,635 & 992,425 & 991,900 & 992,139 \\
\hline P5 & 470331,07 & 4699941,14 & 991,790 & 992,466 & 991,966 & 991,368 & 992,120 \\
\hline P6 & 470324,10 & 4699948,45 & 992,390 & 992,112 & 992,102 & 992,663 & 992,631 \\
\hline P7 & 470295,40 & 4699929,19 & 985,400 & 986,246 & 985,919 & 985,874 & 985,638 \\
\hline P8 & 470301,13 & 4699919,07 & 985,490 & 985,871 & 986,129 & 986,078 & 985,858 \\
\hline P9 & 470282,70 & 4699906,58 & 981,380 & 981,757 & 981,846 & 981,867 & 981,731 \\
\hline P10 & 470274,44 & 4699917,78 & 980,990 & 981,986 & 981,536 & 981,370 & 981,246 \\
\hline P11 & 470252,00 & 4699910,18 & 976,460 & 977,812 & 977,036 & 976,866 & 976,745 \\
\hline P12 & 470254,99 & 4699891,16 & 975,440 & 975,477 & 975,868 & 975,843 & 975,783 \\
\hline P13 & 470230,51 & 4699871,05 & 970,330 & 970,223 & 970,603 & 970,777 & 970,600 \\
\hline P14 & 470222,54 & 4699884,85 & 970,310 & 971,298 & 970,756 & 970,740 & 970,652 \\
\hline P15 & 470215,00 & 4699901,98 & 970,190 & 971,429 & 970,612 & 970,656 & 970,438 \\
\hline P16 & 470205,27 & 4699871,72 & 968,070 & 968,701 & 968,623 & 968,547 & 968,451 \\
\hline P17 & 470199,00 & 4699877,06 & 967,700 & 968,535 & 968,158 & 968,210 & 968,035 \\
\hline P18 & 470183,72 & 4699871,73 & 965,310 & 966,544 & 965,862 & 965,887 & 965,557 \\
\hline P19 & 470185,68 & 4699859,07 & 964,870 & 965,999 & 965,399 & 965,355 & 965,146 \\
\hline P20 & 470160,15 & 4699848,49 & 960,910 & 962,283 & 961,514 & 961,303 & 961,131 \\
\hline P21 & 470144,97 & 4699849,44 & 959,100 & 961,037 & 959,713 & 959,631 & 959,342 \\
\hline P22 & 470127,94 & 4699840,74 & 956,690 & 958,497 & 957,311 & 957,204 & 956,910 \\
\hline P23 & 470123,60 & 4699831,20 & 955,650 & 956,548 & 956,338 & 956,108 & 955,835 \\
\hline P24 & 470104,23 & 4699838,40 & 953,880 & 954,207 & 954,152 & 954,461 & 954,341 \\
\hline P25 & 470093,68 & 4699846,58 & 953,360 & 952,938 & 953,702 & 953,749 & 953,523 \\
\hline P26 & 470093,82 & 4699831,10 & 949,680 & 950,461 & 950,353 & 950,290 & 949,886 \\
\hline $\mathrm{P} 27$ & 470101,49 & 4699817,82 & 949,020 & 949,595 & 949,498 & 949,418 & 949,156 \\
\hline & & & & DTM25 & DTM05 & LIDAR & UAV-SfM \\
\hline & & & RMSEz & $1,443 m$ & $0,483 \mathrm{~m}$ & $0,464 m$ & $0,287 m$ \\
\hline & & & SD & $1,434 m$ & $0,216 \mathrm{~m}$ & $0,200 \mathrm{~m}$ & $0,073 m$ \\
\hline
\end{tabular}



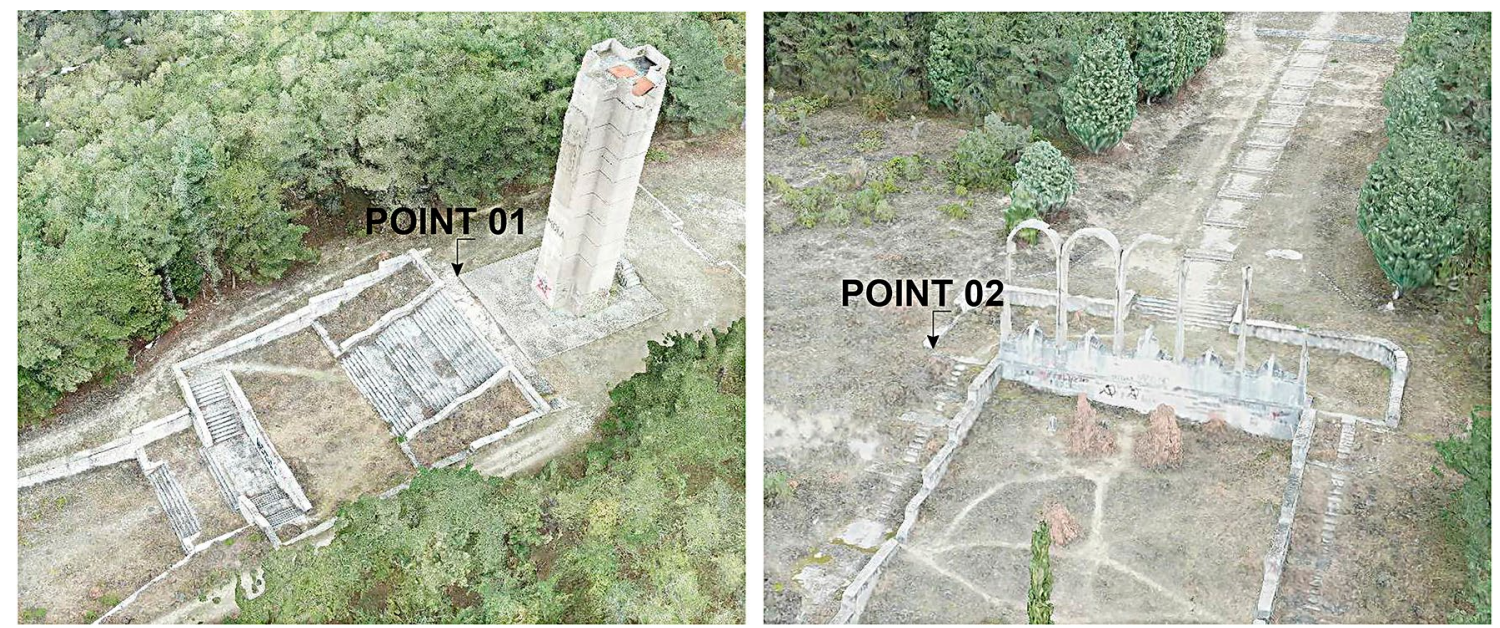

Fig. 4 Auxiliary points P01 and P02

on the surfaces and compare the differences between their heights (Fig. 3). The vertical data from GNSS of these points were transformed into orthometric heights according to the correction from the closest geodesic vertex, number 20113. The RMSEz of the UAV-SfM surface is $28.7 \mathrm{~cm}$ (2 sigma) and the "Standard Deviation" (SD) is $7.3 \mathrm{~cm}$ (2 sigma). Comparing this statistical value with the RMSEz of the other surfaces, the UAV-SfM surface is much more accurate in the representation of the terrain (Table 2).

The altimetric precision of each open public cartographic resource will also be analyzed by comparing the longitudinal profiles of their surfaces with the longitudinal profile of the UAV-SfM. We will also compare the "z" coordinate of the series of points along the longitudinal profile on the maximum gradient of the terrain. This comparison is very important to determine the accuracy of every surface to be used for the site survey, because the maximum gradient of the slope is the axis of the architectural plan of the monument. Therefore, the deviations on the " $\mathrm{z}$ " coordinate along the longitudinal profile of the surfaces will condition the reliability of the cartographic product for this survey.

We chose two points on the limits of the site, P01 and $\mathrm{P} 02$, to generate a longitudinal profile. The line connecting both points is a maximum gradient of the slope. Points were easily identifiable in the ground and on the photographs due to their relationship with the architectural elements of the monument. P01 was placed at the top of the hill on the vertex of a concrete platform. The second point $\mathrm{P} 02$ was placed at the bottom of the slope on the corner of one of the walls of the terraced space surrounding the concrete arches (Fig. 4).

The UTM coordinates in the ETRS 89 of P01 $(470,344.664,4,699,952.497,996.573)$ and $\mathrm{P} 02$ $(470,104.506,4,699,837.969,954.069)$ were taken with GNSS. Vertical data were transformed into orthometric heights according the same correction as the rest of the points of the study case. The horizontal distance between P01 and P02 is 266,086 m and the slope of the terrain between them is $15.97 \%$. Once they were placed on every surface and we have the profiles, we will compare the longitudinal profile of every surface with the profile of the model to analyze the difference in " $\mathrm{z}$ " coordinate every $10 \mathrm{~m}$.

First, we start comparing the surface of the DTM25 with the surface of UAV photogrammetry. The RMSEz of DTM25 is $1.443 \mathrm{~m}$ (2 sigma) (Table 2). We will use the "Mean Error" (ME), the maximum deviation, and the "Standard Deviation" (SD) to analyze the difference in " $\mathrm{z}$ " data along the longitudinal profiles. The maximum deviation is $2.034 \mathrm{~m}$ at P01, the ME is $0.088 \mathrm{~m}$, and the $\mathrm{SD}$ is $0.673 \mathrm{~m}$ ( $3 \mathrm{sigma}$ ). If we analyze the overlap of the maps, the landform of the DTM25 is similar to the model, although point P01 is displaced from the top of the slope. There is also a shift of the maximum gradient of the ground on the DTM25 surface in relation to the axis P01-P02 (Fig. 5).

The second comparison is between the surface of DTM05 and the reference surface. In this area, the RMSEz of DTM05 is $0.483 \mathrm{~m}$ (2 sigma) (Table 2), so it is slightly better than the accuracy of RMSEz $0.5 \mathrm{~m}$ guaranteed by the CNIG. We can verify that in this case, $\mathrm{P} 01$ and $\mathrm{P} 02$ are placed on the DTM05 surface drawing a maximum gradient of the terrain. If we compare the longitudinal profiles, the maximum difference in " $\mathrm{z}$ " coordinates along the profile is $1.079 \mathrm{~m}$, the ME is $0.8 \mathrm{~cm}$, and the SD is $0.398 \mathrm{~m}$ (2 sigma) (Fig. 6).

Finally, we have compared the surface from the LIDAR point cloud and the reference surface from UAV photogrammetry. The RMSEz of the LIDAR surface is $0.464 \mathrm{~m} \mathrm{(2}$ sigma) (Table 2). It is a slightly better accuracy than DTM05 surface accuracy for the study area, and it is a slightly lower precision than the RMSEz $\leq 0.4 \mathrm{~m}$ of the technical 
Fig. 5 Graphic comparison and statistical analysis between surfaces from DTM25 and UAV photogrammetry
Fig. 6 Graphic comparison and statistical analysis between surfaces from DTM05 and UAV photogrammetry

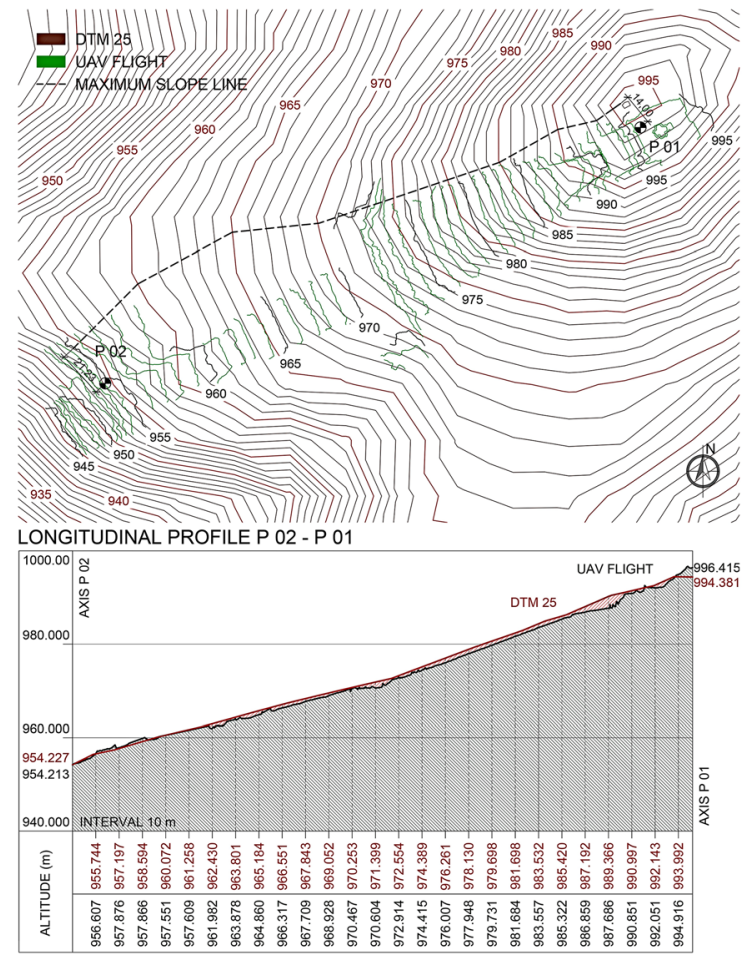

\begin{tabular}{|c|c|c|c|}
\hline \multirow{2}{*}{ POINTS } & \multicolumn{2}{|c|}{ ZCOORDINATE } & \multirow[b]{2}{*}{$\Delta$ "Z" } \\
\hline & DTM25 & UAV-SfM & \\
\hline P02 & 954,227 & 954,213 & $-0,014$ \\
\hline 1 & 955,744 & 956,607 & 0,863 \\
\hline 2 & 957,197 & 957,876 & 0,679 \\
\hline 3 & 958,594 & 959,866 & 1,272 \\
\hline 4 & 960,072 & 960,551 & 0,479 \\
\hline 5 & 961,258 & 961,609 & 0,351 \\
\hline 6 & 962,430 & 961,982 & $-0,448$ \\
\hline 7 & 963,801 & 963,878 & 0,077 \\
\hline 8 & 965,184 & 964,860 & $-0,324$ \\
\hline 9 & 966,551 & 966,317 & $-0,234$ \\
\hline 10 & 967,843 & 967,709 & $-0,134$ \\
\hline 11 & 969,052 & 968,928 & $-0,124$ \\
\hline 12 & 970,253 & 970,467 & 0,214 \\
\hline 13 & 971,399 & 970,604 & $-0,795$ \\
\hline 14 & 972,554 & 972,914 & 0,360 \\
\hline 15 & 974,389 & 974,415 & 0,026 \\
\hline 16 & 976,261 & 976,007 & $-0,254$ \\
\hline 17 & 978,130 & 977,948 & $-0,182$ \\
\hline 18 & 979,698 & 979,731 & 0,033 \\
\hline 19 & 981,698 & 981,684 & $-0,014$ \\
\hline 20 & 983,532 & 983,557 & 0,025 \\
\hline 21 & 985,420 & 985,322 & $-0,098$ \\
\hline 22 & 987,192 & 986,859 & $-0,333$ \\
\hline 23 & 989,366 & 987,686 & $-1,680$ \\
\hline 24 & 990,997 & 990,851 & $-0,146$ \\
\hline 25 & 992,143 & 992,051 & $-0,092$ \\
\hline 26 & 993,992 & 994,916 & 0,924 \\
\hline P01 & 994,381 & 996,415 & 2,034 \\
\hline & ME & 0,088 & \\
\hline & SD & 0,673 & \\
\hline
\end{tabular}

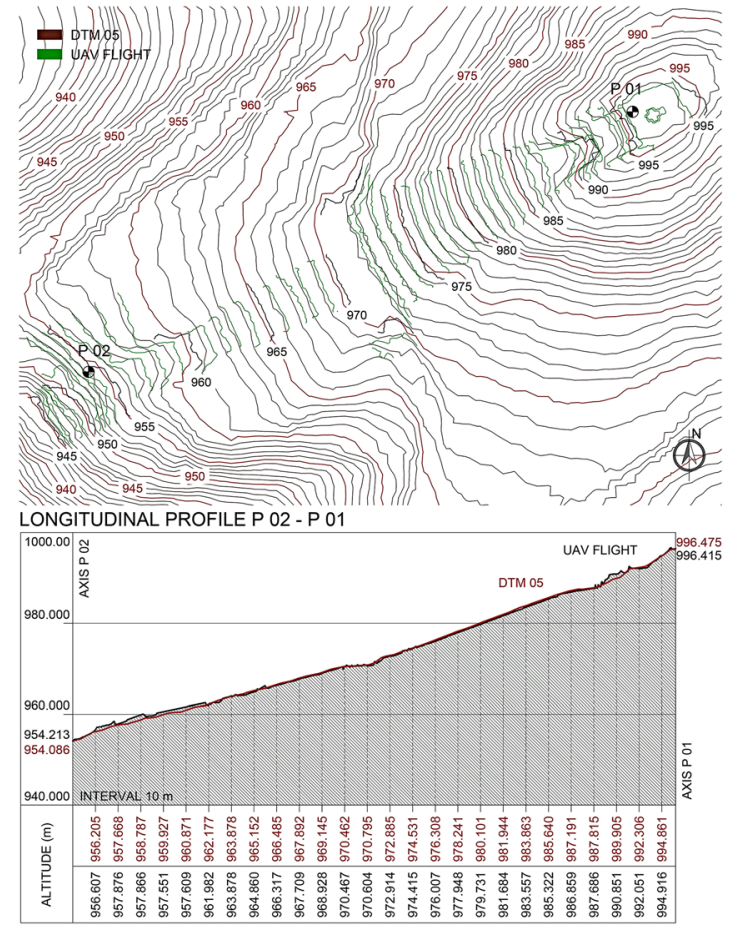

\begin{tabular}{|c|c|c|c|}
\hline \multirow{2}{*}{ POINTS } & \multicolumn{2}{|c|}{ Z COORDINATE } & \multirow{2}{*}{$\Delta " \mathrm{z} "$} \\
\hline & DTM05 & UAV-SfM & \\
\hline $\mathrm{P} 02$ & 954,086 & 954,213 & 0,127 \\
\hline 1 & 956,205 & 956,607 & 0,402 \\
\hline 2 & 957,668 & 957,876 & 0,208 \\
\hline 3 & 958,787 & 959,866 & 1,079 \\
\hline 4 & 959,927 & 960,551 & 0,624 \\
\hline 5 & 960,871 & 961,609 & 0,738 \\
\hline 6 & 962,177 & 961,982 & $-0,195$ \\
\hline 7 & 963,878 & 963,878 & 0,000 \\
\hline 8 & 965,152 & 964,860 & $-0,292$ \\
\hline 9 & 966,485 & 966,317 & $-0,168$ \\
\hline 10 & 967,892 & 967,709 & $-0,183$ \\
\hline 11 & 969,145 & 968.928 & $-0,217$ \\
\hline 12 & 970,462 & 970,467 & 0,005 \\
\hline 13 & 970,795 & 970,604 & $-0,191$ \\
\hline 14 & 972,885 & 972,914 & 0,029 \\
\hline 15 & 974,531 & 974,415 & $-0,116$ \\
\hline 16 & 976,308 & 976,007 & $-0,301$ \\
\hline 17 & 978,241 & 977,948 & $-0,293$ \\
\hline 18 & 980,101 & 979,731 & $-0,370$ \\
\hline 19 & 981,944 & 981,684 & $-0,260$ \\
\hline 20 & 983,863 & 983,557 & $-0,306$ \\
\hline 21 & 985,640 & 985,322 & $-0,318$ \\
\hline 22 & 987,191 & 986,859 & $-0,332$ \\
\hline 23 & 987,815 & 987,686 & $-0,129$ \\
\hline 24 & 989,905 & 990,851 & 0,946 \\
\hline 25 & 992,306 & 992,051 & $-0,255$ \\
\hline 26 & 994,861 & 994,916 & 0,055 \\
\hline P01 & 996,475 & 996,415 & $-0,060$ \\
\hline
\end{tabular}

specifications of the PNOA-LIDAR (Instituto Geográfico Nacional 2020b), and the metadata of the LIDAR file 1st coverage RMSEz of $0.20 \mathrm{~m}$ ( 1 sigma) (Centro Nacional de Información Geográfica 2020b). This difference does not mean that the CNIG metadata are not reliable, but that this study area requires more exhaustive documentation due to the conditions of the land surface that is modified by the remains of the architectural monument.

Nevertheless, by superimposing both surfaces, we observe that the topographic maps represent identical landforms. The contour lines almost coincide in their layout or they have a maximum deviation from the horizontal distance 
Fig. 7 Graphic comparison and statistical analysis between surfaces from LIDAR and UAV photogrammetry

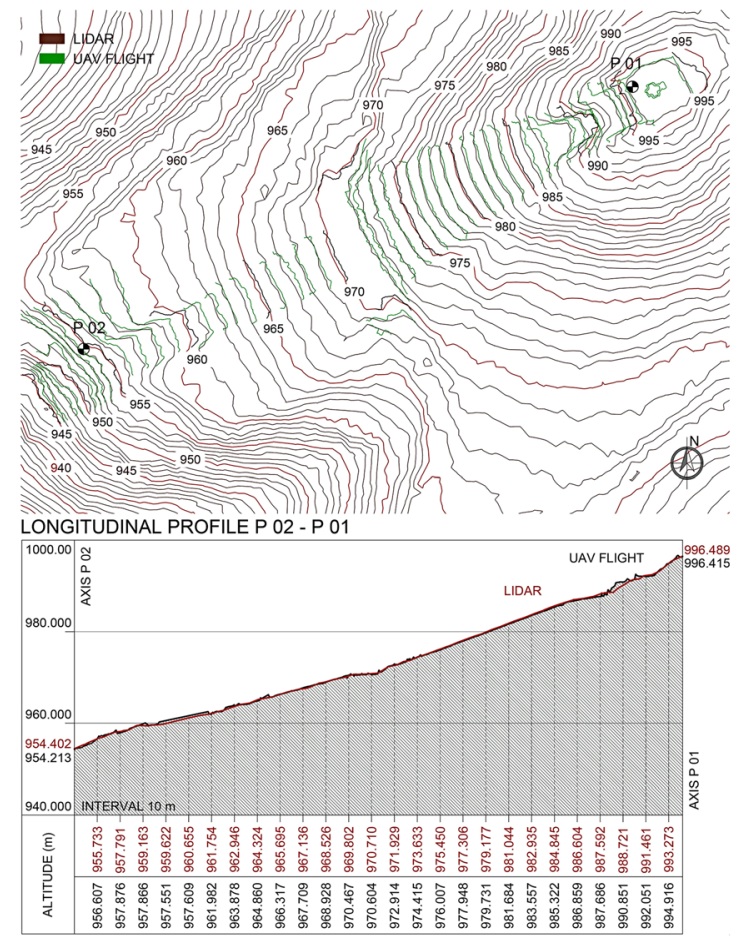

\begin{tabular}{|c|c|c|c|}
\hline \multirow{2}{*}{ POINTS } & \multicolumn{2}{|c|}{ Z COORDINATE } & \multirow{2}{*}{$\Delta$ "Z" } \\
\hline & LIDAR & UAV-SfM & \\
\hline P02 & 954,402 & 954,213 & $-0,189$ \\
\hline 1 & 955,733 & 956,607 & 0,874 \\
\hline 2 & 957,791 & 957,876 & 0,085 \\
\hline 3 & 959,163 & 959,866 & 0.703 \\
\hline 4 & 959,622 & 960,551 & 0,929 \\
\hline 5 & 960,655 & 961,609 & 0,954 \\
\hline 6 & 961,754 & 961,982 & 0.228 \\
\hline 7 & 962,946 & 963,878 & 0,932 \\
\hline 8 & 964,324 & 964,860 & 0,536 \\
\hline 9 & 965,695 & 966,317 & 0,622 \\
\hline 10 & 967,136 & 967,709 & 0,573 \\
\hline 11 & 968,526 & 968,928 & 0,402 \\
\hline 12 & 969,802 & 970,467 & 0,665 \\
\hline 13 & 970,710 & 970,604 & $-0,106$ \\
\hline 14 & 971,929 & 972,914 & 0,985 \\
\hline 15 & 973,633 & 974,415 & 0,782 \\
\hline 16 & 975,450 & 976,007 & 0,557 \\
\hline 17 & 977,306 & 977,948 & 0,642 \\
\hline 18 & 979,177 & 979,731 & 0,554 \\
\hline 19 & 981,044 & 981,684 & 0,640 \\
\hline 20 & 982,935 & 983,557 & 0.622 \\
\hline 21 & 984,845 & 985,322 & 0,477 \\
\hline 22 & 986,604 & 986,859 & 0,255 \\
\hline 23 & 987.592 & 987.686 & 0.094 \\
\hline 24 & 988,721 & 990,851 & 2,130 \\
\hline 25 & 991,461 & 992,051 & 0,590 \\
\hline 26 & 993,273 & 994,916 & 1,643 \\
\hline P01 & 996,489 & 996,415 & $-0,074$ \\
\hline & ME & 0,611 & \\
\hline & SD & 0,489 & \\
\hline
\end{tabular}

of $20 \mathrm{~cm}$. It can even be checked that the quality and characteristics of the contour lines on both surfaces are very similar and they reflect truthfully and expressively the landform. These outcomes agree with the results achieved by other similar research studies comparing both technologies (Bandini et al. 2020).

The horizontal projection of the axis P01-P02 is over the maximum gradient of the terrain. The longitudinal profiles coincide practically in their entire length. The shape of the terrain matches perfectly on both maps. We only have found an outlier at point number 24 , where it is the maximum difference in " $\mathrm{z}$ " coordinates along the profile $2.130 \mathrm{~m}$, but the $\mathrm{ME}$ is $0.661 \mathrm{~m}$, and the $\mathrm{SD}$ is $0.489 \mathrm{~m}$ (1 sigma) (Fig. 7). Therefore, it has been proven that the LIDAR surface is a more detailed topographic description than the DTM05 surface.

\section{Discussion}

The graphic comparison between surfaces is an unquestionable evidence of their similarities and differences in both accuracy and quality of the topographic representation. The research methodology for this study case was based on the hypothesis that the own cartography made with UAV photogrammetry was more accurate than the free cartographic products of the CNIG; therefore, it was used as a reference for comparison. The statistical RMSE for the vertical error of the surfaces has proved the surface from de UAV-SfM is the most accurate, so it can be used as a model to check the quality of the other surfaces to be used in BIM modeling.

According to metadata of the CNIG's LIDAR 1st Coverage (2008-2015), the RMSEz is $20 \mathrm{~cm}$ (1 sigma). This accuracy is similar to the RMSEz of $28.7 \mathrm{~cm}$ ( 2 sigma) we have achieved for the UAV-SfM surface (Table 2). Theoretically, the precision of both surfaces is very similar. However, these outcomes have not been fulfilled in this particular case. The specific conditions of this study area located in a narrow strip of land surrounded by forest with an architectural monument built on the hillside may have distorted the data of the ground of the CNIG's LIDAR 1st Coverage (2008-2015).

The conclusions of this research study could be extrapolated to any other surveys of architecture in the landscape, because landscape architecture consisting of elements such as platforms, slope walls, and stairs modifies the shape of the terrain. For this reason, during the process to create a surface from LIDAR data, it is not possible to classify the points of the architectural elements differentiating them from the ground points in a similar way to how the points are normally classified if they belong to low vegetation or buildings.

Therefore, if the survey is carried out in a site where the shape of the terrain has been modified with architectural elements of landscape architecture, it is important to verify the RMSEz of the CNIG's LIDAR before using this cartographic resource to create the terrain surface. 


\section{Extrapolation of Results for the Site Modeling of a BIM Project}

In 2013, the American Institute of Architects (AIA) defined in a contractual document the levels of development (LOD) that should be contained in projects carried out following the BIM methodology (AIA 2013). The classification in each of the five levels-LOD 100, LOD 200, LOD 300, LOD 400, and LOD 500-refers to the information that a BIM element of the project should contain in relation to the information required by that element to be built (Reyes et al. 2016). Taking as a reference the definition of the levels of development published in the last version of the guide for LOD specifications (AGC The Associated General Contractors of America 2019), we can establish the assimilation with the documentation of a traditional project in Spain (Table 3).

The LOD 100 matches the level of conceptual development of the Previous Studies. This phase corresponds to the analysis and definition of needs. Several design alternatives are studied and ideas are represented without precise geometric definition. The LOD 200 corresponds to the level of development of the Preliminary Plans. At this stage, the geometric design is not defined. It only has a schematic development, but three-dimensional information about the volume and space of every element has already been defined. The LOD 300 includes the geometric definition and the information of the Basic Project, in which the elements have a detailed design. The LOD 400 is the level of development containing the detailed design and the precise information for the bidding and construction of the building.

Finally, the LOD 500 corresponds to the As Built Documentation. In this phase, the virtual model of the building must be completed with the real verification of every element on the building site work. In addition, the LOD 500 must incorporate the Building Manual with the instructions for use and maintenance of the building during its life cycle (Table 3).

Regarding the assimilation of the deliverable milestones of the traditional project in Spain and the levels of development in BIM, there is a certain disparity according to some authors (Oliver 2016; Reyes et al. 2016; Zaragoza Angulo and Morea Núñez 2015). Apart from Oliver 2016, the other authors establish an intermediate level of development LOD 350 that they assimilate to the Execution Project. They highlight the difference between the Execution Project and the Contracting Project that corresponds to LOD 400. Nevertheless, this point does not affect all projects and it is not subject to the level of development of the site modeling.

From the first phases of analysis of the architecture project, the representation of the site is essential, since the surface and shape of the terrain will condition the modeling. The document with the LOD specifications (AGC 2019) differentiates between two types of modeling for site elements "Site preparation" and "Site improvements". The cartographic resources analyzed in this study would serve to represent the original state of the terrain "Site preparation" and could serve as a basis for accurately modeling and quantifying the earthworks required by the terrain modification for the implementation of the "Site improvements" of the project (Table 4).

The BIM User's Guide defines the information required for a BIM model, considering the intended use of the architectural modeling, because its objective will not always be the building. Some recent studies in the field of the application of new technologies in architectural surveys have been aimed at verifying their usefulness in meeting the levels of development required by BIM in an architectural restoration project (Rossi et al. 2020). The objective of a BIM modeling can be a survey of an archaeological site, but it can also be to carry out an energy study or to assess the visual impact of a building on the landscape (BuildingSMART Spanish Chapter 2014a). In these cases, the levels of development of the project must be adjusted to the precision and information required for each assignment, so that many studies will only reach a level of development equivalent to LOD 100 or LOD 200 and will never be developed until LOD 400 or even be built.

If we set the data of the comparative analysis of the surfaces (Figs. 5, 6, 7) (Table 2) and the specifications established by AGC (2019) for the levels of development of site modeling (Tables 3 and 4), we can elaborate a table with the correspondences that the project manager can use as a guide. It determines the suitability of the cartographic

Table 3 Relationship between LOD and traditional documentation. Interpretation made by the authors

\begin{tabular}{ll}
\hline LOD & Geometry design/information \\
\hline LOD 100 & $\begin{array}{l}\text { Elements do not represent the real shape, size, or precise location. Information approximate } \\
\text { EOD 200 }\end{array}$ \\
$\begin{array}{l}\text { Elements may be recognizable as the components they represent, or they may be volumes for space reser- Preliminary plans } \\
\text { vation. Information approximate }\end{array}$ \\
$\begin{array}{l}\text { Elements can be measured directly from the model. Information is attached to the model elements } \\
\text { EOD } 400\end{array} \quad \begin{array}{l}\text { Elements are modeled at sufficient detail and accuracy for fabrication } \\
\text { EOD 500 }\end{array}$
\end{tabular}


Fig. 8 Recommendation for the use of cartographic resources according to the phase of the project. Interpretation made by the authors

\begin{tabular}{|c|c|c|c|c|c|}
\hline \multirow{3}{*}{$L O D$} & \multirow{3}{*}{$\begin{array}{c}\text { PROJET } \\
\text { DOCUMENTS }\end{array}$} & \multicolumn{3}{|c|}{ BIM PROJECT / TRADITIONAL PROJECT } & $\begin{array}{l}\text { IECT } \\
\text { VG }\end{array}$ \\
\hline & & \multicolumn{3}{|c|}{ CARTOGRAPHIC RESOURCES } & \multirow{2}{*}{$\begin{array}{c}\text { OWN } \\
\text { CARTOGRAPHY } \\
\text { UAV } \\
\text { PHOTOGRAMMETRY }\end{array}$} \\
\hline & & DTM 25 & DTM 05 & LIDAR & \\
\hline LOD 100 & Previous Studies & $\mathrm{x}$ & & & \\
\hline LOD 200 & Preliminary Plans & $x$ & & & \\
\hline LOD 300 & Basic Project & & $x$ & $x$ & \\
\hline LOD 400 & Execution Project & & & $x$ & $x$ \\
\hline LOD 500 & As Built & & & $\mathrm{x}$ & $\mathrm{x}$ \\
\hline
\end{tabular}

resources analyzed for the site modeling of an architecture or restoration project according to the level of development determined by the BIM methodology and the documents of a traditional project (Fig. 8).

\section{Conclusions}

The DTMs and LIDAR data provided by the Spanish CNIG to users are guaranteed to give verified and reliable data from the IGN periodically updated. They are cartographic products accessible to the public free of charge. Updates and metadata information are openly available on the internet. The use of these free cartographic resources is a very important competitive advantage for an architecture or engineering firm in the overall cost of a project. However, the use of these products is conditioned to verify their accuracy. According to the results of this research, the viability of their use can be established depending on the object of the work.

The purpose of this comparative study was to verify the accuracy of the surfaces we can draw from the free cartographic resources of the CNIG by comparing them with the map we could elaborate with UAV photogrammetry. In the light of the data obtained in the analysis, we can state that the surface from the DTM25 would be acceptable for the development of architectural or engineering projects whose objective is not the construction, but rather, previous analyses or studies for which the accuracy of the geometric representation is not relevant and simplifying data processing is a priority.

The modeling of the site of an architecture project must be done with at least the DTM05. In this particular study case, we have proved that surfaces obtained from DTM05 and LIDAR point cloud have similar accuracy in RMSEz and SD (Table 2). The graphical quality of the topographic representation is very similar. The graphs of both longitudinal profiles are similar (Figs. 6, 7). There is only one important difference in statistical values that are conditioned by the errors at very specific points (Figs. 6, 7). According all these data, we state that the precision of these cartographic products is valid for the development of the LOD 300 of the project and both of them can be used indistinctly.

For the modeling of the LOD 400, we should make the topographic map using the images captured by a UAV and processed by SfM. We have achieved the most accuracy surface by this process with RMSEz of $28.7 \mathrm{~cm}$ ( 2 sigma). The only possibility to use the surface from CNIG's LIDAR 1st Coverage (2008-2015) is to check the RMSEz is $20 \mathrm{~cm}$ (1 sigma) as it is guaranteed by the CNIG. In this case, this free cartographic product could replace the UAV-SfM surface.

Finally, the level of development LOD 500, according to the BIM User's Guide Document 13, must incorporate the building excavation process documented with laser scanner

Table 4 Level of development of site modeling defined in LOD specifications by AGC (2019), related to traditional project documentation. Interpretation made by the authors

\begin{tabular}{lll}
\hline LOD & Site preparation/site grading & Project documents \\
\hline LOD 100 & A simple topographic surface is provided & Previous studies \\
LOD 200 & Rough modeling of site grading & Preliminary plans \\
LOD 300 & Complete and accurate surface definition & Basic project \\
LOD 400 & Include existing surface generated from site topography and surface modeled & Execution project \\
LOD 500 & Site earthwork process is registered by laser scanning, and it is attached with the "As built" & As built \\
\hline
\end{tabular}


to the "As Built" information model (BuildingSMART Spanish Chapter 2014b). However, the modeling of the existing site to represent the project improvements can be carried out based on the surface generated with the UAV photogrammetry or even the LIDAR surface if the conditions of the CNIG are achieved.

Acknowledgements This research paper is part of the results obtained by the Research Group on Representation of Architecture and the City (GIRAC in Spanish) of the Universidad de Burgos within the framework of the Research Project "Graphic and Documentary Study of Architectures in the Landscape by Aerial Photogrammetry" BU034G19, subsidized by the Consejería de Educación de la Junta de Castilla y León (Spain) for the period 2019-2021. Laboratory of Digital Cartography and 3D Analysis of the National Centre for Research on Human Evolution (CENIEH in Spanish) has collaborated in the fieldwork of this research project. Laboratories of the Department of Graphic Expression of the Universidad de Burgos where the research process was carried out.

Funding Open Access funding provided thanks to the CRUE-CSIC agreement with Springer Nature.

\section{Declarations}

Conflict of interest The authors declare that they have no conflict of interest.

Open Access This article is licensed under a Creative Commons Attribution 4.0 International License, which permits use, sharing, adaptation, distribution and reproduction in any medium or format, as long as you give appropriate credit to the original author(s) and the source, provide a link to the Creative Commons licence, and indicate if changes were made. The images or other third party material in this article are included in the article's Creative Commons licence, unless indicated otherwise in a credit line to the material. If material is not included in the article's Creative Commons licence and your intended use is not permitted by statutory regulation or exceeds the permitted use, you will need to obtain permission directly from the copyright holder. To view a copy of this licence, visit http://creativecommons.org/licenses/by/4.0/.

\section{References}

AGC The Associated General Contractors of America (2019) Level of development (LOD) specification part I and commentary. For building information models and data. https://bimforum.agc.org/ lod/ (Retrieved Aug 20, 2021)

Agüera-Vega F, Carvajal-Ramírez F, Martínez-Carricondo P (2017) Accuracy of digital surface models and orthophotos derived from unmanned aerial vehicle photogrammetry. J Surv Eng. https:// doi.org/10.1061/(ASCE)SU.1943-5428.0000206 (Retrieved Aug 20, 2021)

American Institute of Architects (2013) AIA document G202-2013, building information modelling protocol form. https://www. aiacontracts.org/contract-documents/19016-project-bim-proto col (Retrieved Aug 20, 2021)

Archivo Histórico Provincial de Burgos (1954) Sobre Repoblación Forestal en los términos de Alcocero y Cueva Gardiel para dar buena visibilidad al monumento de Mola. December 18, 1954. Signature 1149/41
Baltsavias EP (1999) A comparison between photogrammetry and laser scanning. ISPRS J Photogramm Remote Sens 54(2-3):8394. https://doi.org/10.1016/S0924-2716(99)00014-3 (Retrieved Aug 20, 2021)

Bandini F, Sunding TP, Linde J, Smith O, Jensen IK, Köppl CJ et al (2020) Unmanned Aerial System (UAS) observations of water surface elevation in a small stream: comparison of radar altimetry, LIDAR and photogrammetry techniques. Remote Sens Environ 237:111487. https://doi.org/10.1016/J.RSE.2019. 111487 (Retrieved Aug 20, 2021)

Bernal A (2018) Arquitecturas efímeras y escenografías de propaganda franquista durante la guerra civil española. Archivo Español De Arte 91(362):159-174. https://doi.org/10.3989/aearte. 2018.11 (Retrieved Aug 20, 2021)

Building SMART Spanish Chapter (2014a) Guía de usuarios BIM. Documento 1. Parte General. https://www.buildingsmart.es/ bim/guías-ubim/ (Retrieved Aug 20, 2021)

Building SMART Spanish Chapter (2014b) Guía de usuarios BIM. Documento 13. Uso de modelos en la parte de construcción. https://www.buildingsmart.es/bim/guías-ubim/ (Retrieved Aug 20, 2021)

Cantemir A, Visan A, Parvulescu N and Dogaru M (2016) The use of multiples data sources in the process of topographic maps updating. Int Arch Photogramm Remote Sens Spatial Inf Sci XLI-B4:19-24. https://doi.org/10.5194/isprs-archives-XLI-B419-2016 (Retrieved Aug 20, 2021)

Carrera-Hernández JJ, Levresse G, Lacan P (2020) Is UAV-SfM surveying ready to replace traditional surveying techniques? Int $\mathrm{J}$ Remote Sens 41(12):4820-4837. https://doi.org/10.1080/01431 161.2020.1727049 (Retrieved Aug 20, 2021)

Centro Nacional de Información Geográfica (2020a) Digital elevation models. http://centrodedescargas.cnig.es/CentroDescargas/ index.jsp (Retrieved Aug 20, 2021)

Centro Nacional de Información Geográfica (2020b) Centro de Descargas. Digital Elevation Models. LIDAR 1st Coverage (2008-2015). Metadata. http://centrodedescargas.cnig.es/Centr oDescargas/index.jsp (Retrieved Aug 20, 2021)

Chiabrando F, Spanò A, Sammartano G, Teppati Losè L (2017) UAV oblique photogrammetry and lidar data acquisition for 3D documentation of the Hercules Fountain. Virtual Archaeol Rev 8(16):83-96. https://doi.org/10.4995/var.2017.5961 (Retrieved Aug 20, 2021)

European Union (2020) European data portal. Datasets. https://www. europeandataportal.eu/data/datasets?locale $=$ enandcountry $=$ esandpage $=1$ (Retrieved Aug 20, 2021)

Höhle J, Höhle M (2009) Accuracy assessment of digital elevation models by means of robust statistical methods. ISPRS J Photogramm Remote Sens 64(4):398-406. https://doi.org/10.1016/J. ISPRSJPRS.2009.02.003 (Retrieved Aug 20, 2021)

Instituto Geográfico Nacional - Centro Nacional de Información Geográfica. (2020). Comparador de Mapas. https://www.ign. es/web/mapasantiguos/index.html (Retrieved Aug 20, 2021)

Instituto Geográfico Nacional (2020a) Centro Nacional de Información Geográfica. https://www.ign.es/web/ign/portal/qsm-cnig (Retrieved Aug 20, 2021)

Instituto Geográfico Nacional (2020b) Plan Nacional de Ortofotografía Aérea. https://pnoa.ign.es/el-proyecto-pnoa-lidar (Retrieved Aug 20, 2021)

Isenburg M (2013) LASzip: lossless compression of LiDAR data. Photogramm Eng Remote Sens. https://doi.org/10.14358/PERS. 79.2.209 (Retrieved Aug 20, 2021)

Jakovljevic G, Govedarica M, Alvarez-Taboada F, Pajic V (2019) Accuracy assessment of deep learning based classification of LiDAR and UAV points clouds for DTM creation and flood risk mapping. Geosciences 9(7):323. https://doi.org/10.3390/geosc iences 9070323 (Retrieved Aug 20, 2021) 
Lorenzo A, Isenburg M, Arbelo M, and Alonso-Benito A (2012) Comparación de modelos digitales del terreno obtenidos mediante LiDAR y técnicas fotogramétricas en una zona forestal de la isla de Tenerife. In: XV Congreso Nacional de Tecnologías de la Información Geográfica. Madrid: AGE-CSIC. http://tig.agegeografia.es/2012_Madrid/ponencia4/Lorenzo_final_imp.pdf (Retrieved Aug 20, 2021)

Moreira JM (2001) La cartografía hoy: ¿evolución o revolución? Las nuevas tecnologías y los cambios en la representación del territorio. In: Actas del Congreso Año mil, año dos mil. Dos milenios en la historia de España. Madrid: Sociedad estatal España nuevo milenio, pp 433-451. http://www.juntadeandalucia.es/medio ambiente/web/Red_informacion_ambiental/productos/Publi caciones/articulos/articulos_pdf/Evolrevo.pdf (Retrieved Aug 20, 2021)

Odón Rodríguez O (2009) Lídar vs. Fotogrametría en la obtención de modelos digitales de elevaciones para estudios hidrológicos. Masters Thesis, Universidad de Salamanca, Escuela Politécnica Superior de Ávila, Spain

Oliver Faubel I (2016) Integración de la Metodología BIM en la programación curricular de los estudios de Grado en Arquitectura Técnica/Ingeniería de Edificación. Diseño de una propuesta. Doctoral Thesis, Universitat Politècnica de València, Spain. https:// doi.org/10.4995/Thesis/10251/61294 (Retrieved Aug 20, 2021)

Peinado Checa ZJ, Fernández Morales A, Agustín Hernández L (2014) Combination of low cost terrestrial and aerial photogrammetry: three-dimensional survey of the church of San Miguel in Ágreda (Soria). Virtual Archaeol Rev 5(10):51-58. https://doi.org/10. 4995/var.2014.4210 (Retrieved Aug 20, 2021)

Previtali M, Valente R (2019) Archaeological documentation and data sharing: digital surveying and open data approach applied to archaeological fieldworks. Virtual Archaeol Rev 10(20):17-27. https://doi.org/10.4995/var.2019.10377 (Retrieved Aug 20, 2021)

Quirós E, Polo ME (2018) Recursos abiertos de información geográfica para investigación y documentación científica. Revista Española De Documentación Científica 41(3):214. https://doi.org/10.3989/ redc.2018.3.1512 (Retrieved Aug 20, 2021)

Reyes AM, Cordero P, Candelario A (2016) BIM Diseño y gestión de la construcción. Anaya, Madrid

Rossi A, Palmero L, Palmieri U (2020) De la digitalización laser hacia el H-BIM: un caso de estudio. EGA Expresión Gráfica
Arquitectónica 25(38):182-193. https://doi.org/10.4995/ega.2020. 12835 (Retrieved Aug 20, 2021)

Rupnik E, Nex F and Remondino F (2013) Automatic orientation of large blocks of oblique images. Int Arch Photogramm Remote Sens Spatial Inf Sci XL-1/W1:299-304. https://doi.org/10.5194/ isprsarchives-XL-1-W1-299-2013 (Retrieved Aug 20, 2021)

Rupnik E, Nex F, Remondino F (2014) Oblique multi-camera systems-orientation and dense matching issues. Int Arch Photogramm Remote Sens Spatial Inf Sci XL-3/W1:107-114. https:// doi.org/10.5194/isprsarchives-XL-3-W1-107-2014 (Retrieved Aug 20, 2021)

Salach A, Bakuła K, Pilarska M, Ostrowski W, Górski K, Kurczyński Z (2018) Accuracy assessment of point clouds from LiDAR and dense image matching acquired using the UAV platform for DTM creation. ISPRS Int J Geo-Inf 7(9):342. https://doi.org/10.3390/ ijgi7090342 (Retrieved Aug 20, 2021)

Tavares da Costa R, Mazzoli P, Bagli S (2019) Limitations posed by free DEMs in watershed studies: the case of river Tanaro in Italy. Front Earth Sci. https://doi.org/10.3389/feart.2019.00141 (Retrieved Aug 20, 2021)

Wang X, Xiao X, Zou Z, Hou L, Qin Y, Dong J et al (2020) Mapping coastal wetlands of China using time series Landsat images in 2018 and Google Earth Engine. ISPRS J Photogramm Remote Sens 163:312-326. https://doi.org/10.1016/J.ISPRSJPRS.2020. 03.014 (Retrieved Aug 20, 2021)

Wiedemann A and Moré J (2012) Orientation strategies for aerial oblique images. Int Arch Photogramm Remote Sens Spatial Inf Sci XXXIX-B1:185-189. https://doi.org/10.5194/isprsarchivesXXXIX-B1-185-2012 (Retrieved Aug 20, 2021)

Zaragoza Angulo JM, Morea Núñez JM (2015) Guía práctica para la implantación de entornos BIM en despachos de arquitectura e ingeniería. Fe d'erratas, Madrid 